\title{
PIZZA KACANG HIJAU INTERVENSI DIET UNTUK ANAK AUTISME DAN ATTENTION DEFICIT HYPERACTIVITY DISORDER (ADHD)
}

\author{
The Green Bean Pizza For Diet Intervention To Autism And Attention Deficit \\ Hyperactivity Disorder Children (ADHD)
}

\author{
Vika Ramadhana Fitriyani, Ainiyatul luklukatul Lababah2, \\ Zakiyah, Aries Chandra Ananditha \\ S1 Keperawatan Fakultas Ilmu Kesehatan Universitas Muhammadiyah Surabaya \\ anandhita.ners@fik.um-surabaya.ac.id
}

\begin{abstract}
ABSTRAK
Anak-anak autis dan ADHD adalah anak berkebutuhan khusus yang harus membutuhkan makanan mereka sendiri. Untuk penderita autisme gluten dan kasein dianggap beracun, karena tubuh dengan autisme tidak menghasilkan enzim mencerna gluten. Akibatnya, protein yang tidak tercerna ini diubah menjadi komponen kimia yang disebut opoids. Opoid sendiri, seperti obat-obatan seperti opium, morfin, dan heroin yang berfungsi sebagai racun yang dapat mengganggu fungsi otak dan sistem kekebalan tubuh, menyebabkan gangguan perilaku. untuk penelitian ini bertujuan untuk menggambarkan pengaruh pizza kacang hijau untuk diet pada anak autis dan ADHD.

Metode yang digunakan dalam penelitian ini adalah studi kasus. Populasi yang diteliti adalah anak-anak dengan autisme dan ADHD. Kasus yang digunakan adalah anak autis. Pengumpulan data dilakukan dengan observasi kepada responden sebelum dan sesudah diberikan Green Peanut Pizza. Teknik analisis data univariat menggunakan kuantitatif.

Dalam pengamatan aktivitas hiperaktif anak sebelum dan sesudah intervensi selama 1 minggu menunjukkan perbaikan. Tingkat hiperaktif anak sebelumnya sering (hampir setiap hari) lebih jarang (kirakira sekali seminggu). Ibu anak melaporkan bahwa anak hanya melakukan perilaku agresif ketika menghadapi situasi yang benar-benar membuat perasaannya emosional.

Green Bean Pizza adalah solusi alternatif untuk diet anak-anak dengan autisme dan ADHD karena terbukti mengurangi tingkat hiperaktivitas pada anak-anak dengan autisme dan ADHD.
\end{abstract}

Kata kunci: Kacang Hijau, Pizza, Autisme, ADHD

\section{A B S T R A C T}

Autism and ADHD children were special need child that have to need their own diets. For autism gluten and casein patients are considered toxic, because the body with autism does not produce enzymes digest gluten. As a result, these undigested proteins are converted into chemical components called opoids. Opoid itself, like drugs such as opium, morphine, and heroin that works as toxins that can interfere with brain function and immune system, causing behavioral disorders. for this study aimed to describe the effect of green bean pizza for diet in children with autism and ADHD.

The method used in this research is case study. The population studied were children with autism and ADHD. Cases used are children with autism. Data collection was done by observation to the respondent before and after given Green Peanut Pizza. Univariate data analysis technique using quantitative.

In the observation of hyperactive activity of children before and after intervention for 1 week showed improvement. The child's previous hyperactive level is often (almost daily) less frequent (approximately once a week). The child's mother reports that the child is only doing aggressive behavior while facing a situation that really makes his feeling emotionally.

Green Bean Pizza is an alternative solution for children's diets with autism and ADHD as it proves to decrease the rate of hyperactivity in children with autism and ADHD.

Keywords:

Green Been, Pizza, Autism, ADHD

\section{PENDAHULUAN}

Autism dan attention deficit hyperactivity disorder (ADHD) adalah ketidakmampua seseorang dalam berinteraksi seperti

berbahasa yang ditunjukkan dengan penguasaan bahasa yang tertunda, echolalia, mutism, pembalikan kalimat, 
memiliki aktivitas bermain repetitive (Centers for Disease Control and Prevention., 2014; Kamps, D. M., Mason, R., \& Heitzman-Powell, L., 2017). Salah satu masalah utama dalam keperawatan pada anak autism dan ADHD adalah gangguan pemenuhan nutrisi atau gangguan pencernaan. (Adams, J. B ., 2018; Li, X. S et al., 2018), sehingga peran perawat juga dibutuhkan dalam penatalaksaan diet autism dan ADHD dengan lintas sectoral atau multidisiplin (Li, X. S et al., 2018). Gangguan saluran pencernaan timbul akibat mekanisme tubuh pada autism tidak mampu mencerna protein, khususnya kasein dan gluten karena tidak aktifnya Enzim dipeptidylpeptidase IV (DPPIV). Hal tersebut yang menyebabkan terjadinya penumpukan opioid pada otak sehingga penderita kehilangan kontrol pada dirinya termasuk penguasaan bahasa dan interaksi sosial serta system imunitas (Engel, M et al., 2003; Tucker, I., 2017).

Prevalensi autism di Indonesia mencapai 6.900 anak pertahunya (Mashabi \& Tajudin NR., 2009). Berdasarkan studi pendahuluan bahwa RSU dr.Soetomo Surabaya menunjukkan jumlah penderita autism meningkat setiap tahun. Pada tahun 2009 terdapat 92 pasien autism dan meningkat pada tahun 2010 menjadi 100 pasien serta 125 pasien pada tahun 2011 . Bagi autism minuman pengganti protein susu yang mengandung kasien dang lutein pada protein gandum atau terigu dapat menyebabkan alergi dan menurunnya kesehatan penyandang autis dan ADHD (Curtis, L. T., \& Patel, K., 2008), oleh karena itu perlu adanya alternatif pengganti bahan makanan tersebut (Levy, S. E., \& Hyman, S. L., 2008)

Salah satu jajan camilan yang cukup di gemari oleh anak-anak termasuk para penderita autism yaitu roti seperti pizza, pie dan biskuit (Pirson F., 2006), namun saat ini belum banyak pizza di pasaran yang khusus di Indonesia yang diperuntukkan untuk autism dan ADHD yang tidak mengandung gluten dan kasein. Salah satu tepung yang bebas dari kasein dan glutein adalah tepung kacang hijau (Tanjung, Y. L. R., \& Kusnadi, J., 2014).dan tepung kentang (Pratiwi, R. A.,
\& Dieny, F. F., 2014; Nareswara, A. R., \& Anjani, G., 2016) yang dapat digunakan sebagai bahan dasar pembuatan pizza. Formulasi jajanan sehat berupa pizza yang berbahan dasar tepung kacang hijau dan tepung kentang dikembangkan dan diteliti untuk memenuhi kebutuhan gizi khusus bagi penderita autism dan ADHD. Penelitian ini bertujuan untuk mengenai karakteristik organoleptik dan kimia pizza berbahan baku tepung kacang hijau sehingga diperoleh jajanan sehat bebas kasein dan gluten bagi penderita autism dan ADHD

\section{BAHAN DAN METODE \\ Bahan}

Bahan dasar dalam pembuatan pizza adalah tepung kacang hijau dan tepung kentang . Bahan pembantu berupa garam himalaya, minyak bunga matahari

Alat

Peralatan yang digunakan dalam pembuatan produk adalah mixer, timbangan digital, loyang, kompor, cetakan pizza, alat oven, baskom plastik.

\section{Tahapan}

Pembuatan pizza. Proses pembuatan pizza meliputi tahap persiapan, penyangraian tepung, pencampuran, pembuatan adonan, pencetakan adonan, pemanggangan dan pendinginan.

\section{Metode}

Metode penelitian yang wawancara terkait uji organoleptik (fisik) dan uji laboratorium (kimiawi) yang dilakukan untuk membuktikan kualitas pizza kacang hijau.

\section{Prosedur Analisis}

Pada penelitian ini analisis yang digunakan yaitu meliputi analisis kadar air metode thermogravimetri analisis kadar abu, analisis kadar lemak metode soxhlet, analisis profil protein metode Elektroforesis SDS PAGE, analisis warna dengan color reader, analisis daya patah dengan tensile strength.

\section{HASIL DAN PEMBAHASAN}




\section{Karakteristik fisik dan kimiawi pizza kacang hijau fortifikasi tepung kentang}

Bahan-bahan ang digunakan dalam pembuatan pizza free gluten dan bebas kasein adalah tepung kacang hijau fortifikasi tepung kentang. Adapun analisis yang dilakukan pada pizza kacang hijau yaitu analisis kadar abu, air, lemak, dan pati yang dapat dilihat pada Tabel 1.

Tabel 1. Karakteristik Uji Kimiawai pizza kacang hijau

\begin{tabular}{lcc}
\hline \multirow{2}{*}{ Parameter } & \multicolumn{2}{c}{ Pizza Kacang Hijau } \\
\cline { 2 - 3 } & $\begin{array}{c}\text { Hasil } \\
\text { Analisis }\end{array}$ & Literatur \\
\hline $\begin{array}{l}\text { Kadar Abu } \\
(\%)\end{array}$ & 0.44 & Maks 2.07 \\
\hline $\begin{array}{l}\text { Kadar Air } \\
(\%)\end{array}$ & 6.53 & 5.07 \\
\hline $\begin{array}{l}\text { Kadar } \\
\text { Lemak (\%) }\end{array}$ & 0.06 & maks 0.09 \\
\hline $\begin{array}{l}\text { Kadar Pati } \\
(\%)\end{array}$ & 42.29 & 43,05 \\
\hline $\begin{array}{l}\text { Kadar } \\
\text { Glutein }\end{array}$ & - & 0.02 \\
\hline $\begin{array}{l}\text { Kadar } \\
\text { Kasein }\end{array}$ & - & 0.01 \\
\hline
\end{tabular}

Berdasarkan tabel diatas diketahui untuk tepung kacang hijau fortifikasi tepung kentang dan bahan penunjang lainnya memiliki hasil analisis yang tidak jauh beda dengan nilai diliteratur, maka dari pizza ini dapat dikonsumsi oleh anak autis dan ADHD

\section{Karakteristik Organoleptik}

Pengujian organoleptik merupakan cara pengujian menggunakan indera manusia sebagai alat utama untuk mengukur daya terima terhadap makanan. Analisis ini dilakukan pada 31 orang panelis. Karena adanya kesulitan untuk mendapatkannya maka hanya ada 24 orang penderita autis dan sisanya adalah panelis non autis seperti guru anak autis dan dokter serta ahli gizi. Parameter yang diujikan yaitu rasa, tekstur, aroma dan warna. Hasil uji oragoleptik dapat dilihat pada Tabel 2.
Tabel 2. Hasil Uji Organoleptik

\begin{tabular}{cc}
\hline Parameter & Nilai \\
\hline Rasa & 3.40 (Netral) \\
\hline Tekstur & 3.78 (Disukai) \\
\hline Aroma & 3.61 (Disukai) \\
\hline Warna & 3.72 (Disukai) \\
\hline
\end{tabular}

\section{KESIMPULAN}

Hasil uji elektroforesis membuktikan bahwa di sample pizza tepung kacang hijau tidak terdapat gluten maupun kasein serta memilki kandungan gizi yang sesuai dengan rekomendasi SNI makanan autis dan ADHD

\section{SARAN}

Perlu dilakukan analisis lebih lanjut terakit uji cerna pada pizza kicang hijau. Pada penelitian ini tidak dilakukan analisis statistik dikarena tidak ada variasi komposisi resepi, sehingga tidak ada komposisi atau kelompok terbaik. Oleh karena itu perlu adanya metode eksperimental.

\section{DAFTAR PUSTAKA}

Adams, J. B., Audhya, T., Geis, E., Gehn, E., Fimbres, V., Pollard, E. L., ... \& Matthews, J. S. (2018). Comprehensive nutritional and dietary intervention for autism spectrum disorder - a randomized, controlled 12-month trial. Nutrients, 10(3), 369

Centers for Disease Control and Prevention. (2014). CDC estimates 1 in 68 children has been identified with autism spectrum disorder, 2014.

Curtis, L. T., \& Patel, K. (2008). Nutritional and environmental approaches to preventing and treating autism and attention deficit hyperactivity disorder (ADHD): a review. The Journal of Alternative and Complementary Medicine, 14(1), 79-85.

Engel, M., Hoffmann, T., Wagner, L., Wermann, M., Heiser, U., Kiefersauer, R., ... \& Brandstetter, H. (2003). The crystal structure of dipeptidyl peptidase IV (CD26) reveals its functional regulation and enzymatic mechanism. Proceedings of the 
National Academy of Sciences, 100(9), 5063-5068.

Kamps, D. M., Mason, R., \& HeitzmanPowell, L. (2017). Peer Mediation Interventions to Improve Social and Communication Skills for Children and Youth with Autism Spectrum Disorders. In Handbook of Social Skills and Autism Spectrum Disorder (pp. 257-283). Springer, Cham.

Levy, S. E., \& Hyman, S. L. (2008). Complementary and alternative medicine treatments for children with autism spectrum disorders. Child and adolescent psychiatric clinics of North America, 17(4), 803-820.

Li, X. S., Pinto-Martin, J. A., Thompson, A., Chittams, J., \& Kral, T. V. (2018). Weight status, diet quality, perceived stress, and functional health of caregivers of children with autism spectrum disorder. Journal for Specialists in Pediatric Nursing, 23(1), e12205.

Mashabi, N. A., \& Tajudin, N. R. (2009). Hubungan antara pengetahuan gizi ibu dengan pola makan anak autis. Makara Kesehatan, 13(2), 84-86.

Nareswara, A. R., \& Anjani, G. (2016). Studi Tentang Susu Almond Dan Kentang Sebagai Alternatif Minuman Fungsional Untuk Anak Autis (Doctoral dissertation, Diponegoro University).

Pirson F. (2006). Food Allergy: A Challenge For The Clinician. Acta Gastroenterol Belg, Vol.69: 38-42

Pratiwi, R. A., \& Dieny, F. F. (2014). Hubungan skor frekuensi diet bebas gluten bebas casein dengan skor perilaku autis(Doctoral dissertation, Diponegoro University).

Tanjung, Y. L. R., \& Kusnadi, J. (2014). BISKUIT BEBAS GLUTEN DAN BEBAS KASEIN BAGI PENDERITA AUTIS [IN PRESS JANUARI 2015]. Jurnal Pangan dan Agroindustri, 3(1), 11-22.
Tucker, I. (2017). Autism, Nutrition, ADHD. Autism. 